\title{
Development and Evaluation of the Effectiveness of Computer-Assisted Physics Instruction
}

\author{
Mohd. Jasmy Abd Rahman ${ }^{1}$, Mohd. Arif. Hj. Ismail ${ }^{2} \&$ Muhammad Nasir $^{3}$ \\ ${ }^{1}$ Faculty of Education, Universiti Kebangsaan Malaysia, Malaysia \\ ${ }^{2}$ National PERMATA pintar Centre, Malaysia \\ ${ }^{3}$ Physics Education, Universiti of Riau Indonesia, Pekanbaru, Indonesia \\ Correspondence: Mohd. Jasmy Abd Rahman, Faculty of Education, Universiti Kebangsaan Malaysia, 43600 \\ UKM Bangi, Selangor, Malaysia. Tel: 603-8921-6257.E-mail: mjas@ukm.edu.my
}

Received: August 19, 2014 Accepted: November 18, 2014 Online Published: December 21, 2014

doi:10.5539/ies.v7n13p14 URL: http://dx.doi.org/10.5539/ies.v7n13p14

\begin{abstract}
This study aims to design and develop an interactive software for teaching and learning physics about motion and vectors analysis. This study also assesses its effectiveness in classroom and assesses the learning motivation of SMA Pekanbaru's students. The software is developed using ADDIE Model design and Life Cycle Model and built using the program Delphi Seventh version by considering design, technical, pedagogical, and the content of its learning material. The research was conducted through quasi-experiment upon XI grade students of SMA Pekanbaru. The evaluation of the software was done by the experts of design, pedagogic, technical, and learning material. After the evaluation, this software was also evaluated by expert users consisting of 31 experienced physics teachers from senior high schools in Pekanbaru. The population consisted of six classes XI grade students of SMA Pekanbaru, where two of them are randomly selected. One of the two classes, then, was determined as experimental group while the other as control group. The experimental group consisted of 38 students, with 19 boys and 19 girls whereas the control group consisted of 37 students with 17 boys and 19 girls. The sampling was based on homogeneity and normality test. The finding shows that the reliability based on Cronbach Alpha is $\alpha=0.740$. Learning physics using interactive software "Motion and Vector Analysis" has affected students' conceptual understanding by 81.16 compared to students learning using traditional method, which was only 35.86. Through t-test, it was found that students' conceptual understanding was different from value $\mathrm{t}=-22.725, \mathrm{p}=0.00$ with $\alpha=0.05$. Students' motivation to learn in the post-test was better for students who learn using the software than those who learned using traditional method. Finding based on gender found that the conceptual understanding of male students and female students were similar. Learning motivation for both male and female students has also increased. Therefore, learning physics with "Motion and Vectors Analysis" topics using interactive software is more effective than learning using traditional method.
\end{abstract}

Keywords: interactive software development, motion, vectors analysis, physics, Delphi Method

\section{Introduction}

Globalization as the impact of revolution in information and communication technology has brought changes in every aspects of life. The most prominent changes are in terms of economy and science (Entis, 2007). In term of economy, globalization has created new economic order, while for science it makes science development much faster.

Physics is a branch of science that underlies the development of advanced technology and the concept of harmony with nature. The rapid development in the technology of information and communication is driven by the invention of physics through the discovery of micro electronic materials. However, number of studies found that many students have difficulty in learning the concepts, principles, theories and laws of physics. The majority of physics teachers in Indonesia are poor of creativity, insight, knowledge, and not progressive. In addition, healso stated that the result of research education in the learning process as not been optimally utilized to improve the quality of future teachers of physics. In line with the statement that physics education is still amomok (scary thing), the graduates are still less in number when compared to other disciplines. This is also due to the monotonous manner or method used by teachers. 
Therefore, the researchers has conducted this study to build a software, by referring to KTSP (Curriculum Education Units (BSNP, 2006) which will provide the Motion and Vector Analysis topic in class X state Senior High School (SMA) in Pekanbaru, Riau, Indonesia. The implementation of science teaching in Indonesia is still at a low level. Daily lessons are just filled with lectures and discourses that give more emphasis to approach the concept or product in the form of memorization. On the other hand, students tend to have difficulty in memorizing the concept given. In many cases, students only spend time learning to fill in a log book, listening to the teacher's explanation and doing the monotonous exercises. In the performance of traditional learning, the teacher asked the students to absorb but do not use, listen but do not act, theorized but not practicing. Students' job is only memorizing ideas and facts, not to apply the concept in action. Therefore, it is important to develop a strategy that enables students and at the same time achieve the goals of science learning outlines.

Teaching and learning of science should implement a wide range of methods and approaches that provide opportunities for the students' exploration through relevant activities that enable them to build meaningful conceptual understanding. Gatiwisnu-Indriyana (2009), finds that Learning Physics is monotonous and focused on teachers, rarely use laboratories for lack of facilities and infrastructure, lack of media variation.

Another thing that causes the above case is the lack of appropriate media to be used for delivering message and avoiding misconceptions. In science education, interaction between objects and students are necessary. If it is not possible, the teacher should be able to make a modification, it could be a model of real objector visualization through other media.

On the other hand, physical material always requires an understanding of the concept which is difficult to do only through imagination as an abstract and sometimes difficult to observe it (Saprisoma, 2008), but it still has to be understood deeply Yohanes-Surya (2006) and Werdhiana et al. (2008). This is the cause of students not having fun in Physics. Misconception in learning physics is due to many factors, such as lack of practicum, model analogy used, narrow model of demonstration (Supriyono, 1999). According to Table 1, the final examination results of physics education in 2001 to2007 in the Riau province is not satisfying and tends to decrease.

Table 1. Final examination result of physics subject in 2001-2007

\begin{tabular}{llllllll}
\hline \multirow{2}{*}{ Subject } & \multicolumn{7}{c}{ Year } \\
\cline { 2 - 8 } & 2001 & 2002 & 2003 & 2004 & 2005 & 2006 & 2007 \\
\hline PHYSIC & $\mathbf{5 . 2 0}$ & $\mathbf{5 . 1 1}$ & $\mathbf{4 . 7 9}$ & $\mathbf{4 . 7 6}$ & $\mathbf{4 . 8 5}$ & $\mathbf{4 . 3 8}$ & $\mathbf{4 . 4 3}$ \\
\hline
\end{tabular}

Source: Department of Education, Rau Province, 2008.

Seeing from the questions given in the analysis of the test results, most of the students could not answer questions on physics concepts (Maharta, 2008). While most concept is about motion, i.e. the vector analysis in class X (BSNP, 2003) later revised by BSNP (2006). In addition, as reported by Suparno (2005), the low understanding in the physics concepts is due to lack of laboratory experiment and media studies; this is also in line with the findings of Enti-Suntina (2007) and Dian (2007). Besides, the ability factor and teachers' salaries is still small, Suparno (2005).

Based on the explanation above, the authors would like to develop learning software for physics about motion by making the visualization of the motions of objects that can be organized and interact with students and teachers. Teachers are expected to give encouragement. If a teacher works to create the conditions that motivate and enactive students' learning, it would be possible to increase the performance of learning to achieve learning goals that have been set.

\section{Research Questions}

Physicis part of Natural Science (IPA) in the way to find out about natural phenomena systematically, so it is not just the mastery of knowledge in the form of facts, concepts, or principles but a process of discovery. IPA Educationis expected to be a media for learners to learn about themselves and the environment, and to apply it in everyday life. The learning process emphasizes on the direct experience to develop competencies so thatl earners can explore and understand environment scientifically. Physics science education is directed to find out and by doing so can help learners to gain a deeper understanding of the environment.

As the study of natural phenomena, physics also gives a good lesson to people to live in line with the natural law. Management of natural resources and the environment as well as reducing the impact of natural disasters will not 
run optimally without a good understanding of physics. At the level of SMA/MA, physics is considered important to be taught as separate subjects with a several considerations. Firstly, in addition to providing knowledge to the learners, Physics is also intended as a media to foster thinking skills that are useful for solving problems in everyday life. Secondly, physics needs to be taught for a more specific purpose to equip learners with knowledge, understanding and a total capacity that is required to enter a higher educational level, and to develop knowledge and technology. Learning Physics as scientific inquiry is applied to cultivate the ability to think, work, behave, and communicate scientifically as one of the important aspects of life skills. However, the learning has yet to attract students to intensify learning physics (Mundilarto, 2005); it can be seen from the result of the final exam of high school students in Pekanbaru City that tends to decrease in the last 6 years.

Physics aims to develop students' ability to have a positive attitude towards physics by realizing the regularity and beauty of nature and the glory of God Almighty. Fostering scientific attitude that is honest, objective, open, resilient, critical and can work with others.

Physics is still considered as difficult lessons as well as scary, so that the number of physics graduates is far fewer if we compare to other subjects. This is because the lesson is less interesting to students. Difficulties and problems faced by students PKA must be overcome by using an effective strategy of teaching and learning. CAL that has much strength is the potential to enhance the effectiveness of teaching and learning.

Based on the problem statement mentioned above the research questions to be resolved are as following:

\subsection{Software Development}

An interactive software development about motion and vector analysis for XI grade students of senior high school in Physics subject was developed. Research questions were comprised of the following aspects:

How significant does the interactive software for motion and vector analysis topics meet the technical aspects in software development?

How significant does the interactive software for motion and vector analysis topics meet the pedagogical aspects in software development?

How significant does the interactive software for motion and vector analysis topics meet the content aspects in software development?

How significant does the interactive software for motion and vector analysis topics meet the aspects of design in software development?

\subsection{Effectiveness Evaluation of Software Development}

Research questions comprise of the following aspects:

How significant can the developed software improve the Physics learning outcomes for state SMA students in Pekanbaru?

How significant can the developed software improve the Physics learning motivation for state SMA students in Pekanbaru?

How significant can the developed software improve the Physics learning interest for state SMA students in Pekanbaru?

\section{Research Methodology}

The software was developed by referring to the ADDIE model (Norton \& Wiburg, 2003). According to Hannum and Hansen (1989) and Gibbons (1981), a common feature found in instructional design model has produced a generic instructional design model or a model of a generic ID is also known as the ADDIE model which stands for Analysis, Design, Development, Implementation and Evaluation. ADDIE model is a generic model with a systematic approach, the directional design process. The model provides a frame work to ensure that the products developed are effective, According to Siemens (2002), the ADDIE is the best and the most commonly used in multimedia development. Each phase in the ADDIE model has an output and this output becomes the input to the next phase. The processes of these models are generally linear from one phase to the next phase.

Morrison \& Kemp (2007) states that, in the design of multimedia software, the process that occurs are not as easy as the original process of ADDIE model. According to them, the ADDIE model was developed in an integrated manner with the principles of multimedia instructional design. Based on Enhanced ADDIE Model, this systematic process is cyclical and repetitive, and the beginning process of this model is the analysis phase, followed by a phase of design, development, implementation, (with elements that focus on formative assessment). After the product as required has been created, then the summative evaluation will be conducted to 
validate the effectiveness of the product.

Development of the interactive physics for motion and vector analysis for XI grade students is a combination of directional design and software life cycle methodology. ADDIE model (modified by Norton and Wiburg) has been studied and used as a basis for modelling he development of course ware for physics' motion and vector analysis grade XI. According to Kruse (2005), the ADDIE model is still used by many researchers. Besides, the researchers also included a phase of Rapid Prototyping in addition to the development phase of the ADDIE model. To produce a good model, the development process for the CD-ROM or Web-based programs should use the modified ADDIE model, based on a systematic approach. The Rapid Prototyping should be inserted as a contribution to the design phase of the ADD IE model. Thus, the prototype developed in this study was inserted in Prototyping processing he development phase of the ADDIE model.

From the Figure 1, it can be seen that this study begins with the planning software interactive using the ADDIE model then made into a CD (Compact Disk), evaluated by material/curriculum experts, pedagogic and information technology experts of programming. Along with that, the evaluation is also done by users, in this case are physics teachers with at least five years teaching experience.

From the evaluation and assessment performed by the experts of technique, Pedagogic, content on aspects of design, pedagogy, and Technical, the Cronbach Alpha was obtained. In addition, in line with the assessment by experts, the evaluation are also done by experienced users in terms of ease of use and run the software in the classroom. The validity and reliability were also obtained from this assessment.

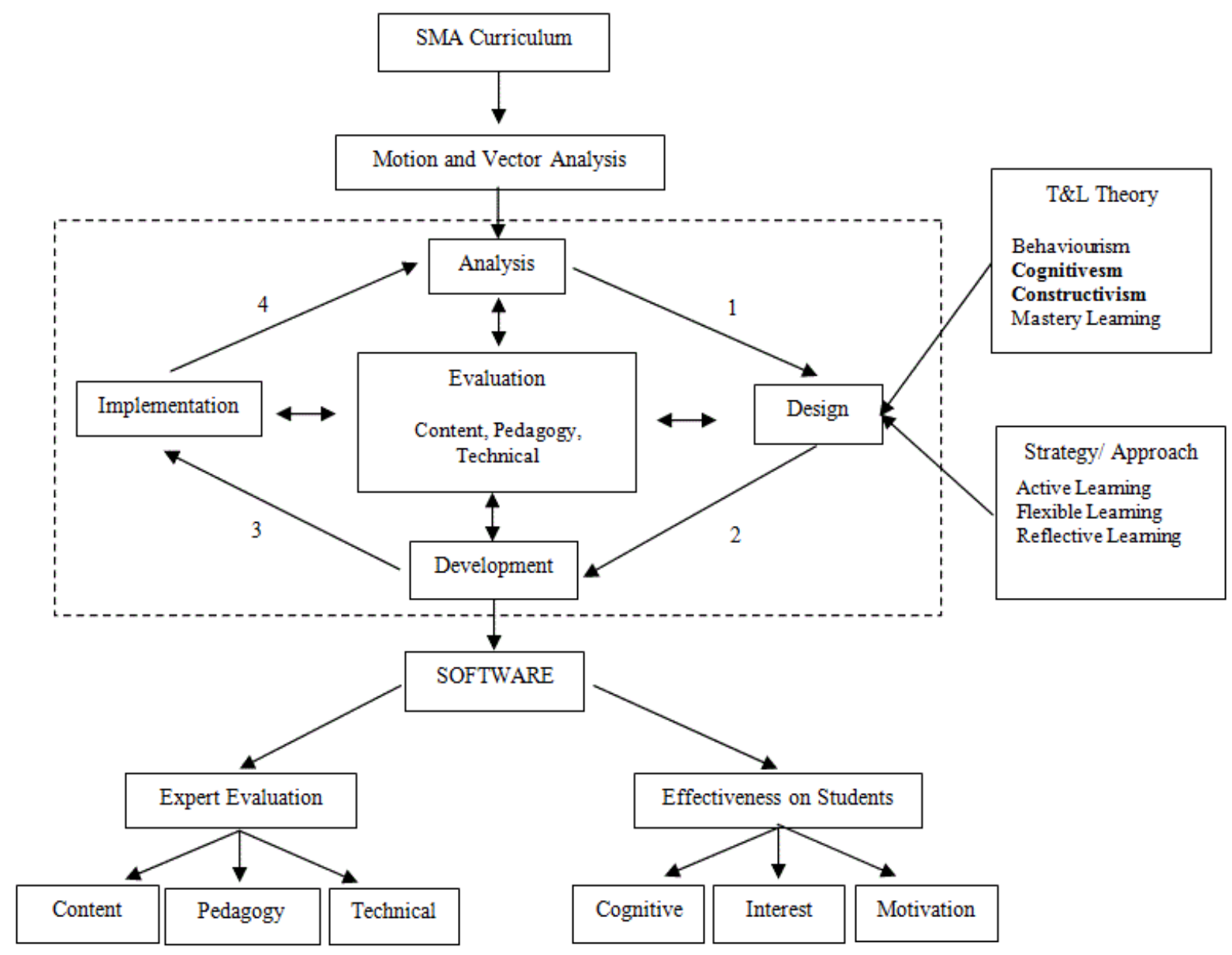

Figure 1. Research's conceptual framework

\section{Research Finding}

The softwarehas successfullyplanned anddeveloped as in following Figure 2, Figure 3, Figure 4, Figure 5, Figure 
6 and Figure 7:

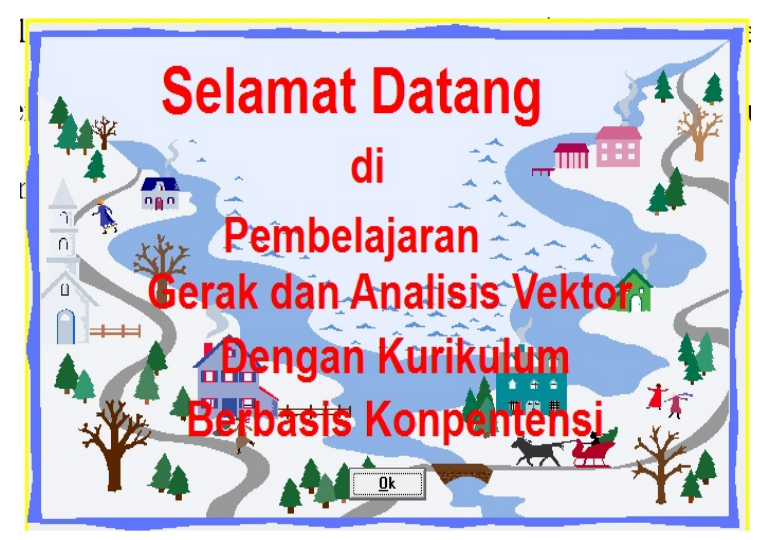

Figure 2. Home page

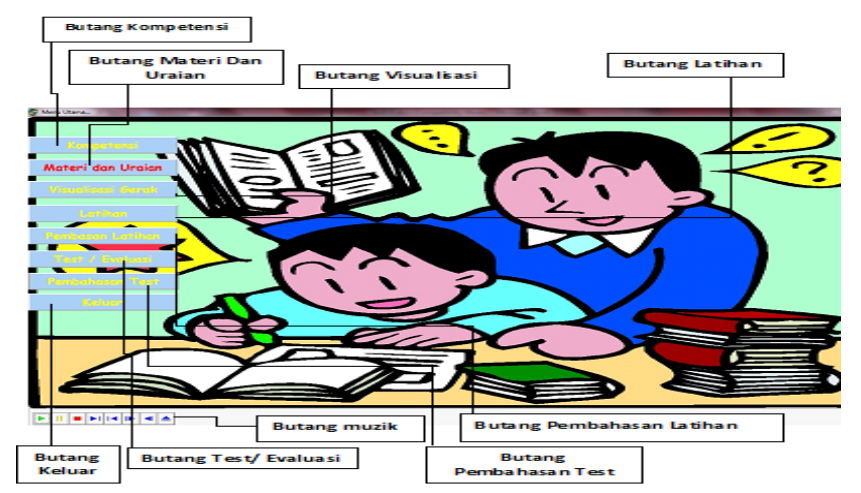

Figure 3. Main menu screen

Three experts have respectively taken from each field o give evaluation on the software in terms of technique, content or pedagogy. Thus, 9 people will give evaluation on the software that has been built. The findings can be seen on the following Table 1:

Table 1. Assessment schedule of technical, pedagogical, and contentexperts upon interactive multimedia "motion and vector analysis

\begin{tabular}{lll}
\hline Cronbach's Alpha & $\begin{array}{l}\text { Cronbach's Alpha Based on Standardized } \\
\text { Items }\end{array}$ & N of Items \\
\hline .843 & .846 & 24 \\
\hline
\end{tabular}

In addition to the above findings, a pilot study was also conducted in SMA Pekanbaru, for gaining validity and reliability software as shown on Table 2:

Table 2. Reliability finding based on expert users

\begin{tabular}{lll}
\hline Cronbach's Alpha & $\begin{array}{l}\text { Cronbach's Alpha Based on Standardized } \\
\text { Items }\end{array}$ & N of Items \\
\hline .843 & .845 & 24 \\
\hline
\end{tabular}




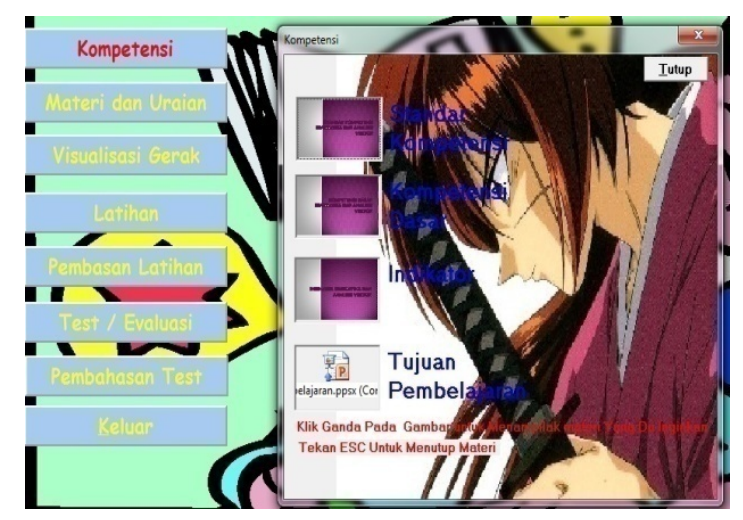

Figure 4. Learning competence display

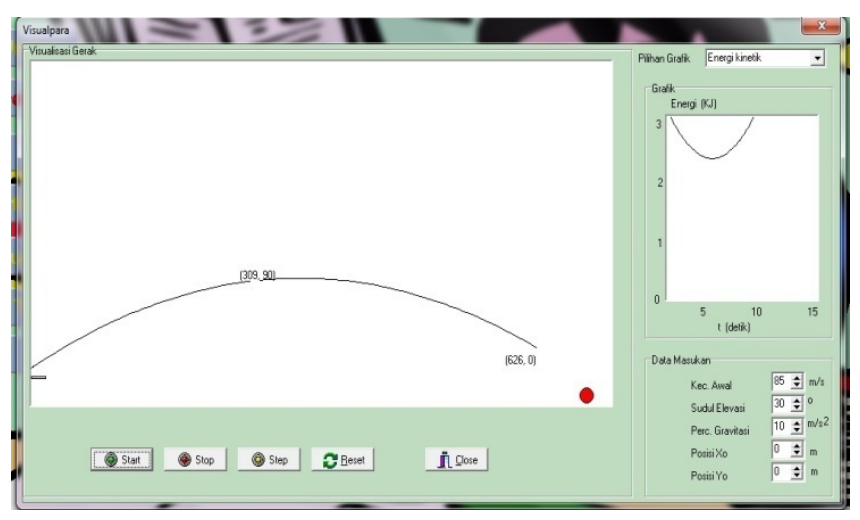

Figure 5. Parabolic motion and motion component display

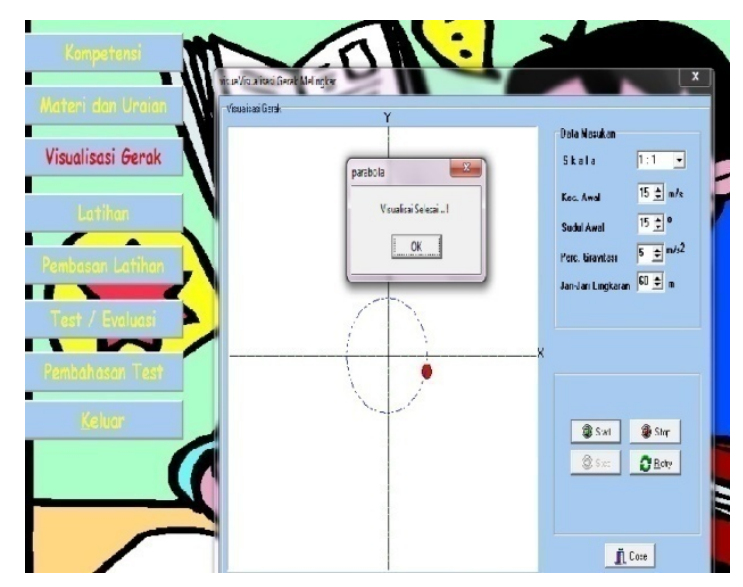

Figure 6. Circular motion display 


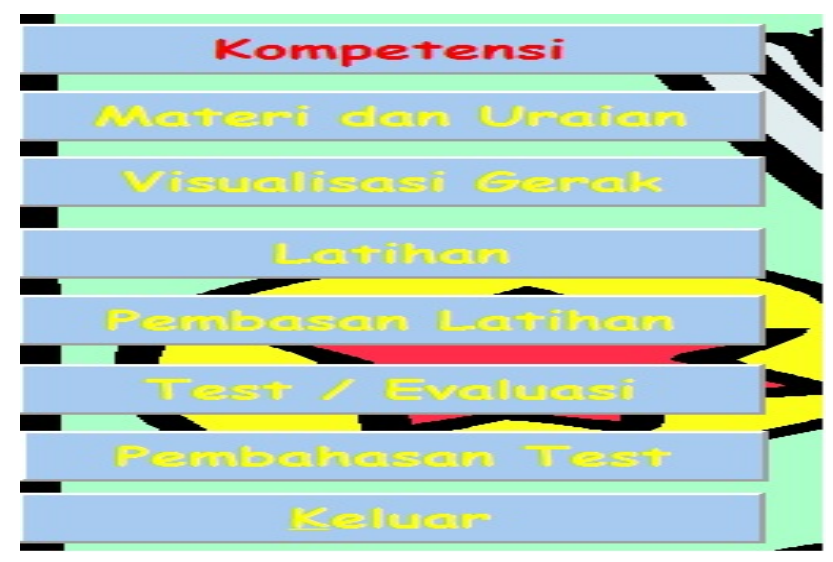

Figure 7. Menu/ learning options

Analysis result done by experts is shown in tables below:

Table 3. Software assessment done by experts in developing period as a whole

\begin{tabular}{lllll}
\hline Aspects & Questions & Min & $\begin{array}{l}\text { Standard } \\
\text { Deviation }\end{array}$ & Variants \\
\hline Design & $1-10$ & 4.11 & 0.54 & 0.30 \\
Pedagogic & $11-20$ & 4.01 & 0.46 & 0.24 \\
Content & $21-30$ & 4.21 & 0.40 & 0.22 \\
Technical & $31-38$ & 4.18 & 0.40 & 0.16 \\
\hline Total & $\mathbf{1 - 3 8}$ & $\mathbf{4 . 1 2}$ & $\mathbf{0 . 4 3}$ & $\mathbf{0 . 2 1}$ \\
\hline
\end{tabular}

Table 4. Assessment done by expert users as a whole $(\mathrm{N}=31)$

\begin{tabular}{llll}
\hline Aspects & Questions & Min & Standard Deviation \\
\hline Design & $1-10$ & 4.03 & 0.52 \\
Pedagogic & $11-20$ & 3.97 & 0.62 \\
Content & $21-30$ & 3.76 & 0.64 \\
Technical & $31-38$ & 4.02 & 0.66 \\
\hline Total & $\mathbf{3 8}$ & $\mathbf{3 . 9 5}$ & $\mathbf{0 . 4 0}$ \\
\hline
\end{tabular}

Table 5. T-testonpre-test and post-test comparing the comprehension of physics "motion and vector analysis" between experimental and control group

\begin{tabular}{lllllll}
\hline Test & Group & N & Min & $\begin{array}{l}\text { Standard } \\
\text { Deviation }\end{array}$ & t-Value & $\begin{array}{l}\text { Step } \\
\text { Sig }\end{array}$ \\
\hline \multirow{2}{*}{ Pre- } & Experimental & 38 & 39.815 & 7.871 & 1.93 & 0.07 \\
& Control & 36 & 35.858 & 9.828 & & $0.01^{*}$ \\
\multirow{2}{*}{ Post } & Experimental & 38 & 81.350 & 8.080 & 10.67 & \\
& Control & 36 & 61.595 & 7.813 & &
\end{tabular}

Based on Table 5, it is shown that no significant difference in student achievement in the pre-test between the control group and the experimental group $(t=1.93: \mathrm{p}=0.07)$. This showed that the concept of motion and vector analysis topics in the early stages before the experiment was carried out at the same level between the 
experimental group $($ mean $=39.82)$ and control group $($ mean $=35.86)$.

Table 6. Couplet-test comparing concepts mastery physics topics motion and vector analysis between pre and post-test for experimental group

\begin{tabular}{|c|c|c|c|c|c|c|c|}
\hline Test & Min & $\mathrm{N}$ & $\begin{array}{l}\text { Standard } \\
\text { Deviation }\end{array}$ & $\begin{array}{l}\text { Difference Score } \\
\text { Min }\end{array}$ & t-value & $\mathrm{dk}$ & Sig \\
\hline Pre- & 39.815 & 36 & 7.871 & -41.353 & -22.725 & 37 & $.001 *$ \\
\hline Post- & 81.350 & 36 & 8.080 & & & & \\
\hline
\end{tabular}

* Significantat $\mathrm{p}<0.05$.

Table 7. T-test comparing concepts mastery physics topics motion and vector analysis between pre and post-test for experimental group

\begin{tabular}{lllllll}
\hline Test & Group & N & Min & $\begin{array}{l}\text { Standard } \\
\text { Deviation }\end{array}$ & t-value & Sig \\
\hline \multirow{2}{*}{ Post } & Experimental & 38 & 84.526 & 11.607 & 8.102 & $0.01^{*}$ \\
& Control & 36 & 59.472 & 14.871 & & \\
\hline
\end{tabular}

* Significantat $\mathrm{p}<0.05$.

Table 8. Result of pre-test and post-test for experimental and control group

\begin{tabular}{lllllll}
\hline Test & Group & N & Min & $\begin{array}{l}\text { Standard } \\
\text { Deviation }\end{array}$ & t-value & Sig \\
\hline \multirow{2}{*}{ Pre } & Experimental & 38 & 3.05 & 0.22 & 1.60 & 0.12 \\
& Control & 36 & 3.03 & 0.17 & 0.49 & 6.44 \\
\multirow{2}{*}{ Post } & Experimental & 38 & 3.39 & 0.23 & $0.01^{*}$ \\
& Control & 36 & 3.06 & & \\
\hline
\end{tabular}

* Significantat $\mathrm{p}<0.05$.

\section{Conclusion}

The results of this study found that there are three main aspects, namely acquired computer aided software development methods in the teaching and learning of physics, computer-aided evaluation of the effectiveness of teaching and learning physics and increase motivation to learn from the state High School (SMA 9 Pekanbaru, Riau.

Models of software development for computer-assisted teaching and learning physics known as Holistic Model of Life Cycle Interactive Physics Learning Software Development is based on the ADDIE model of instructional design methodologies (Model ID) and the prototyping process in software engineering methodology or life cycle software methodologies. The developed life-cycle model is more comprehensive as it incorporates the ADDIE model, prototyping, model ID, software interface, teaching and learning environment and learning objectives. This software is physics learning software that is based on the Education Unit Level Curriculum (KTSP) for students in high school (SMA). Previously existing software was built by a non-education person therefore; it does not carry the pedagogical aspects. Despite of first time use, it has been significantly successful compared to the use of traditional methods. This implies that the software should be recommended for all high school in Pekanbaru, or even for all over Indonesia. Therefore, the administrator or education planners must include this computer-assisted in teaching and learning physic into curriculum so that it becomes compulsory for any high schools.

\section{References}

Cresswell. (2005). Educational research: Planning, conducting, and evaluation quantative and qualitative 
research. Boston: Pearson Education, Ltd

Departemen Pendidikan Nasional. (2003). Pedoman khusus pengembangan silabus dan penilaian. Jakarta.

Dian, S. (2007). Implementasi Life Skill dalam KTSP. Mughni Sejahtera Bandung.

Entis, S. (2007). Jurnal Teknodik. No. 10/VI/Teknodik/Okotober/2002. PustekkomDepdiknas.

GatiwisnuIndriyani. (2009). Penerapan Model Problem Base Instruction padamata Diklat Fisika Bahasan Hukum Newton Tentang Gerak di Untuk melatih Kemampuan Berfikir Kritis Pelajar Kelas X SMA Negeri 2 Kebumen (Unpublished article). Indonesia.

Keanginan, M. (2006). FISIKA untuk SMA Kelas XI, Erlangga. Jakarta.

Liao, H.-C. (2008). Applying The ARCS Motivation Model In Technological And Vocational Education, Contemporary Issues In Education Research-Second Quarter, 1(253).

Martinis, Y. M. P. (2008). Paradigma Pendidikan Konstruktivisitik. Gaung Persada Press, Jakarta.

Morrison, G. R., Ross, S. T., \& Kemp, J. E. (2007). Design effective instruction. John Wiley \& Son Inc.

Newby, T., Stepich, D., Lehman, J., \& Russel, J. (2006). Educational Technology for teaching and learning (3rd ed.). New Jersey: Pearson Merril Prentice Hall.

Norton, P., \& Wiburg, K. M. (2003). Teaching with technology (2nd ed.). Beltmonnt: Wadswoth, Thomson Learning Inc.

Sardiman, A. M. (2007). Interaksi dan motivasi belajar mengajar. Jakarta: PT. Raja Grafindo Persada.

Sparisoma, V. (2008). Miskonsep sida lam pengajaran fisika: Kenyataan di lapangan. Center A, Institut Teknologi Bandung 16-17 July, 2008.

Stanislaus, S. U. (2009). Pedoman analisis data dengan SPSS. PT. Yogyakarta: Garha Ilmu.

Suhaida, A. K. (2002). Perbandingan Pembelajaran Koopertif dan Tradisional Terhadap Prestasi, Konsep Kendiri, Atribusi Pencapaian, Konsep Kendiri Akademik dan Hubungan Sosial Dalam Pendidikan Perakuanan (Unpublished $\mathrm{PhD}$ thesis). Universiti Putra Malaysia, Malaysia.

Wina, S., \& Edisipertama, M. P. (2008). Perencanaan dan desain sistem pembelajaran. Jakarta: PT. Prenada Media Group.

\section{Copyrights}

Copyright for this article is retained by the author(s), with first publication rights granted to the journal.

This is an open-access article distributed under the terms and conditions of the Creative Commons Attribution license (http://creativecommons.org/licenses/by/3.0/). 